\title{
Memory politics in transition: Nostalgia tours and gilded memories of Petsamo
}

Maria Lähteenmäki, University of Eastern Finland, Department of Geographical and Historical Studies

Alfred Colpaert, University of Eastern Finland, Department of Geographical and Historical Studies

\section{Abstract}

The paper examines politics of memory related to the Arctic Finnish-Russian-Norwegian borderland, Petsamo-Pechenga. How it has been remembered, shared and interpreted after the Second World War by refugees from Finnish Petsamo and their offspring, on the one hand, and Finnish public writing, on the other hand? Which means have been used to revitalize their collective and personal narratives and construct the geohistorical space of Petsamo? During the Second World War, Petsamo was the focus of the Arctic conflict, and at the end of the war, Finland lost the region to the Soviet Union. Our source material comprises 521 articles, which we analyzed using qualitative and text mining methods. We conclude that compared with the other war refugee communities in Finland, Petsamo is peripheral to Finnish public post-war memory politics and nostalgia tourism. This is for several reasons: the fact that people from Petsamo constituted a minority among the Finnish evacuees $(5200$ of 420,000$)$ and were subdivided into two groups (Finns and Skolt Sami people), the devastated and polluted environment, militarization and closeness of Russian Pechenga until the 1990s. The politics of memory about Petsamo - such as nostalgia tourism, written memories, monuments, intergenerational experiences of landscape and history books - can be seen as a manifestation of collective sorrow for a lost homeland, both as individual therapeutic surrender and creating a special emotional community of ex-Petsamo people.

Keywords: politics of memory, nostalgia tourism, war refugees, Finnish-Russian Arctic borderland, text mining 


\section{Introduction: research design}

The research question of this empirical study is to present and analyze the post-war politics of memory related to the Arctic region of Petsamo in the European High North. The politics of memory will be addressed in three ways: nostalgia tourism, written data related to the Petsamo, and the public reminiscence activity of Petsamo NGOs (monuments, history books). The revitalizers of the Petsamo memories are both Finnish amateur historians and journalists, and war refugees from Petsamo and their descendants. As Maurantonio $(2014$, p. 2) has stated, the politics of memory 'engages the questions of who wants whom to remember what, and why'. In focusing on the politics of memory, researchers move from the individual toward socially oriented understanding that considers memory as part of a broader network of relationships.

The design of our research rests in the historical context and approach. During the years 1945-2015, the geohistory of the northernmost part of Europe changed dramatically, and the region transformed quite rapidly from a Finnish peripheral and exotic colony to a Russian, highly industrialized and polluted area. Geohistory means the geographical history of a region in which history is interpreted based on geographical factors (Baker, 2003, pp. 62-71). That is, here, the unique space and location of Finnish Petsamo by the Arctic Ocean far from the center of power (distance from Helsinki some $1300 \mathrm{~km}$ ), and between the Soviet Union and Norway, a member state of NATO (e.g. Lähteenmäki, 2016, pp. 179-180). Petsamo, and its tourism, was characterized by its northern location $\left(69.5^{\circ} \mathrm{N}\right)$ on the coast of the Arctic Ocean. The region has a unique Finnish historical background, which makes it interesting in the context of the Barents Region, and Arctic tourism as well (Elenius, Tjelmeland, Lähteenmäki, \& Golubev, 2015). Petsamo (Skolt Sami: Peäccam, Russian: Pechenga), a total area of $10,370 \mathrm{~km}^{2}$, has been a special area for Finns. It was their gateway to the Arctic Ocean and a narrow borderland, about $50 \mathrm{~km}$ wide and $200 \mathrm{~km}$ long, located between Finnish Lapland, Kola Peninsula in the Soviet Union, and the province of Finnmarken in Northern Norway (Figure 1).

The Arctic natural landscape of Petsamo is contoured with low rounded fells (highest peaks slightly over 600 meters above sea level). Three river systems flow into the Arctic Ocean, providing opportunities for salmon fisheries. Most of the area belongs to the northern boreal taiga forest zone; higher areas have Alpine birth forests and treeless tundra. From a Finnish perspective, perhaps the most important natural feature has been the Arctic coast. Strategically and economically, the key resource is Kolosjoki nickel ore, discovered in the early 1920s. Construction of the mine started in 1930 and full production was reached in 1943. After the war, the Soviet Union (USSR) restarted the mining operations. Today Nikel is a major northern Russian center for mining and smelting. When Finland ceded Petsamo to the Soviet Union in September 1944, it dramatically lost its geohistorical position as an Arctic coastal state.

After pre-mapping our source material, the nostalgia tours were identified as one of the most hegemonic discourses in terms of Petsamo memory politics. Finnish nostalgia tourism to lost Petsamo, however, has been modest compared to nostalgia tourism to lost Karelia, which has been the main destination for the Karelian evacuees, who were able to travel to the ceded areas of Karelia as early as the 1950s. The experiences of Karelian refugees have dominated research (e.g. Armstrong, 2004; Savolainen, 2015): they have been the subject of 200 doctoral 
theses between 1948-2013 (Raninen-Siiskonen, 2013). In comparison, Petsamo has yielded only a few dissertations, which focused mainly on the Finnish era (1920-44) (Krosby, 1967; Kuusikko, 1996; Rautio, 2003; Vuorisjärvi, 1990). From this viewpoint, our paper deals with the history of neglected minorities, and there are no previous academic studies about Finnish nostalgia tourism in post-war Petsamo.
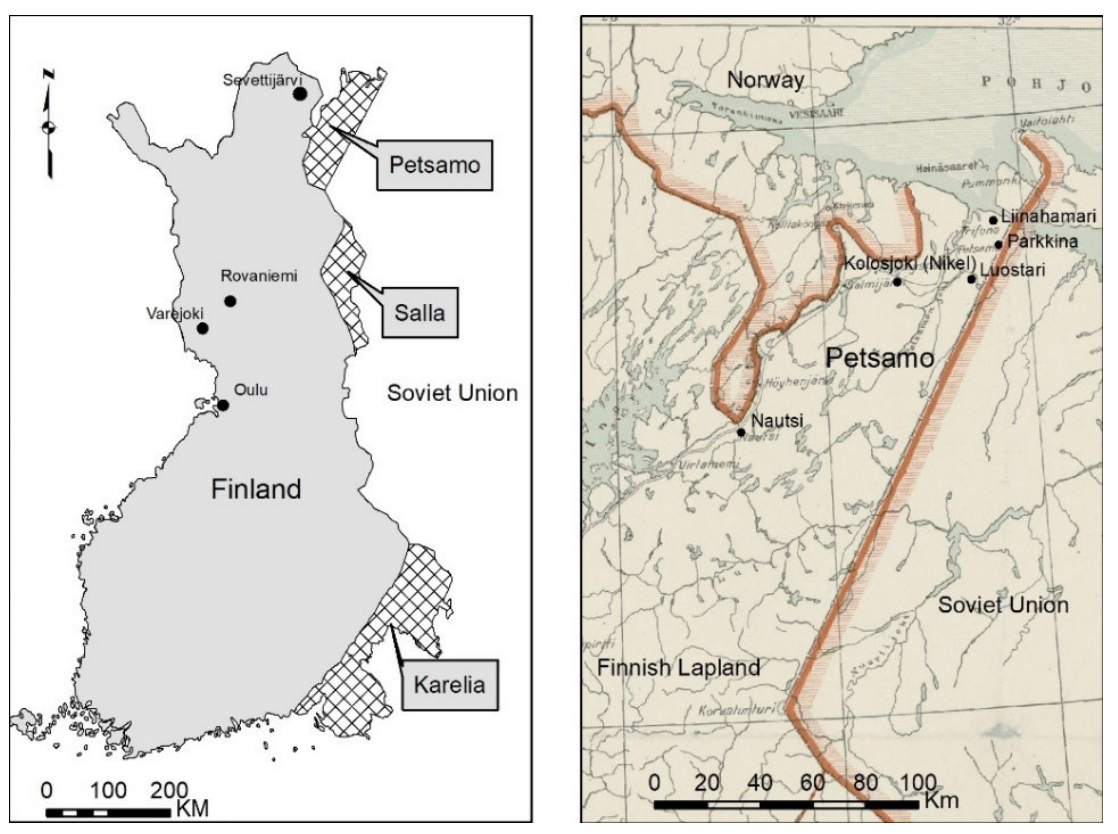

Figure 1. Finnish Petsamo and Finnish territorial losses in 1944. (Maps: Alfred Colpaert 2019.) The number of the Karelian evacuees in 1944 was some 407,000 (97\% of all Finnish evacuees). The Salla evacuees numbered 3300, and the Petsamo evacuees about 5200. The Karelians had to move around Southern Finland. The majority of the Finnish Petsamo people resettled in Southern Lapland in Varejoki; 400 Skolt Sami from Petsamo got new homes across the new border in Sevettiiärvi near their old homeland, and the Salla inhabitants resettled just on the Finnish side of the border in their home region.

As Boym (2001) has argued, nostalgia discourse becomes more general due to deep societal changes, globalization and ethnic confrontations. Thus it is not surprising that, in the 2010s, nostalgia tourism is again a topical issue. This complex phenomenon can be defined in many ways. We adopt the definition introduced by Marschall (2015a) when she retraced the path of her parents, who were war refugees from Poland. She refers to nostalgia tourism as 'homesick tourism', and 'personal memory tourism'. Personal memory tourism, according to her, is a form of travel motivated by memories of one's own past and focused on revisiting of sites and places associated with key moments in a person's life or the retracing of memorable journeys. It can involve revisiting favorite childhood holiday spots and returning to one's former home, school, place of work or any other personal memory site. Marschall (2015a, pp. 876, 879, 880-881) has also highlighted other concepts, such as 'migrant return travel' and 'roots tourism' that focus on tourists who rely on tours to search for their own ancestral roots. 
The second hegemonic discourse in terms of Petsamo memory politics has been the work of the Petsamo Society (Petsamo-Seura). To strengthen the collective Petsamo reminiscence and identity, the war refugees have established three NGOs, the working-class Evacuees of Petsamo (1945-1960s) (Petsamon siirtoväki, 1978), the more right-wing Turja Union (1950-1960s) (Melamies, 2017, pp. 62-63, 74, 77-79), and a new non-political Petsamo Society (1972), which (in 2019) has about 400 members. Numbers diminish year after year, so it has become increasingly important to collect immaterial heritage (oral history, reminiscences, poems etc.) and material objects from the region. Heritage is not only about the past: it is a process of engagement, an act of communication and making meaning from and for the present (Smith, 2005, p. 1). Due to the diaspora of Petsamo evacuees around Lapland, integrative societies have been indispensable. Above all, they are emotional communities. Rosenwein (2010) defines these as largely the same as social communities - families, neighborhoods or academic institutions. But researchers studying these communities seek to uncover systems of feeling, to establish what they (and the individuals within them) find valuable or harmful; the emotions that they value, devalue, or ignore; the nature of the affective bonds between people that they recognize; and the modes of emotional expression that they expect, encourage, tolerate, and deplore (Rosenwein, 2010, p. 11).

\section{Material and methods: the Petsamo corpora}

The third important factor in the memory politics of Petsamo has been public writings in Finnish newspapers and magazines. Our main source material comprises texts on Petsamo written by Finnish journalists and amateur historians; altogether, the material contains 463 digitalized texts (the Petsamo corpus). The basic source texts have been collected systematically from the Finnish national database FINNA (1945-2015). A systematic search for the Finnish keyword 'Petsamo' was made using all the texts. The source material in question contains also the Petsamo articles in the leading daily newspaper of Finland Helsingin Sanomat (1990-2015). These 463 texts have been analyzed using quantitative methods, such as text mining (Berry \& Kogan, 2010; Burdick, Drucker, Lunenfeld, Presner, \& Schnapp, 2011; Gold, 2012; Mone, 2016).

Our second collection of source material (the NGO corpus) is based upon evacuees' stories extracted from the annual magazine Petsamolaista (1975-2015) published by the Petsamo Society. The material contains 58 collected, scanned and digitalized articles related to reminiscences and tours of Petsamo, assessed qualitatively using thematic analysis. The analysis emphasizes pinpointing and examining themes within data. It goes beyond simply counting phrases or words in a text and moves on to identifying implicit and explicit ideas in the data. Our approach emphasizes the subjective human experience, that is, participants' perceptions, feelings and experiences (e.g. Guest, MacQueen, \& Namey, 2012, pp. 11-12).

All 521 texts were scanned, after which the image data (PDF format) was transformed to text format using the OCR (Optical Character Recognition) capabilities of the open source R-software ( $\mathrm{R}$ Core Team, 2017). Package magick was used to improve image quality (despeckling, noise reduction and contrast enhancement). The OCR transformation was done using tesseract software (Ooms, 2017). The separate text documents were read into a corpus word database using 
the package tm (Feinerer \& Hornick, 2017). For all subsequent text mining analysis, we used the $\mathrm{R}$ packages tm and wordcloud (Fellows, 2014). Stemming was not used to retain subtle meanings of Finnish words. It must be noted that the occurrence of images, dark areas and newspaper column hyphening resulted in a substantial amount of unreadable text. This garbage as well as the usual stop words had to be removed before further analysis. All capital letters were changed to lower case. Punctuation, hyphens and other special characters, as well as all numbers, were removed. In addition, we removed the word 'Petsamo', including 'Petsamon', 'Petsamoon' and other variants, resulting from the large number of cases in Finnish grammar (15 cases), as this was the keyword for the search and consequently dominated all texts. The corpus was divided into seven ten-year intervals to analyze the temporal aspect of public writings. The year 2015 was treated separately, as it did not fit into the ten-year interval: however, this year provides information on the future orientation in the Petsamo reminiscence.

To complement the text analysis and to get a more authentic view of the emotions and visual interpretations, our source material includes seven video documents of nostalgia tours to Petsamo organized by the Petsamo Society in 1997-2013. These video documents have been loaned by society activists, who chose the movies especially important for them, so they are fruitful sources in this context. In addition, the first named author of this article, Maria Lähteenmäki, visited Petsamo twice $(2014,2015)$ with members of the Petsamo Society. ${ }^{1}$

By the 2010s, many Petsamo refugees had passed away, but their stories live on through their descendants, and the desire to search for family roots. Today's memories of Petsamo are mostly second-hand memories, re-memories or post-memories, as researchers have called them. Re-memory, according to Tolia-Kelly (2004, p. 316), is memory that is encountered in the everyday, but is not always a recollection or reflection of actual experience, and is told to you by others, e.g. parents. It is an inscription of time in place, which is touched, accessed or mediated through sensory stimuli. Re-memory is a resource for the sustenance of a sense of self that temporally connects to social heritage, genealogy, and acts as a resource for identification with place. According to Hirsch (2012, pp. 29-54), apart from the generation who have directly experienced war, memories of traumatic events live on to mark the lives of those who were not there to experience them. Halbwachs (1952/1992, p. 51) has also stated that through collective memories people can remember things and events where they were not present. Young (2018) called the memories of the generation born after the Second World War second-hand memories. These people do not remember actual events, but rather the countless histories, novels, and poems they have read, and the photographs, movie and video testimonies they have seen over the years. They remember long days and nights in the company of survivors, listening to their harrowing tales, until their lives, loves, and losses seem grafted onto their own life stories (Young, 2018). For instance, on the 2005 nostalgia trip to Petsamo, only seven of the 35 participants were actually born there; the remaining travelers were second and third generation descendants and people interested in the history of Petsamo (movie, Petsamo-Murmansk, 16-19/6/2005).

In our study the term 'first generation of Petsamo people' refers to the people who were born in Petsamo or spent their childhood there, and reminisced about it in the 1970s and 1980s.

1 We would like to thank Toivo 'Topi' Kunnari and the other members of Petsamo Society for the fruitful co-operation. 
We have only a few memories from the 1940s-1960s: instead, this period was dominated by the resettlement process, building new homes and farms. Correspondingly, 'the second and third generations of Petsamo people' means offspring of the first generation, who published their writings on Petsamo from the 1990 s onwards.

Before embarking on a qualitative and quantitative analysis of the written data and public reminiscence (books and monuments) of Petsamo, we briefly introduce the temporal value and spatial dimension of this Arctic region for Finns. Historical value and the temporal dimension frame our analysis: it is crucial to recognize these elements in order to understand the Finnish politics of memory related to Petsamo after the Second World War.

\section{Temporal value of Petsamo}

Arctic Lapland and Petsamo have a special meaning for Finns, and to understand this we need to review the geohistory of the region. Finns inhabited the Arctic coast during the nineteenth century, but their ancestors had traveled, hunted, fished, built huts and occasional homes there for centuries before. Much later, they became known as Kvens (Niemi, 1995). The first mention of a permanent Finnish settlement in the Petsamo region (Paatsjoki/Pasvik River Valley) is in 1851. The Russian crown released a settlement statement for the Murman Coast in 1860, and many Finns and Norwegians from Northern Norway and Finnish Lapland moved to the Russian side of the coast and established villages. ${ }^{2}$ The main reason for this move was poor living conditions in their earlier home areas. Finnish politicians followed this migration with increasing anxiety, and they started to demand that a Finnicized area of the Russian coast be ceded to Finland, calling it by its Finnish name, Petsamo. Nationalist Finnish scientists found Petsamo as well. Between 1820 and 1917 some 70 Finnish researchers did fieldwork in the Kola Peninsula (Lähteenmäki, 2017, pp. 45-59; Rantala, 2008, p. 12).

The first inhabitants of the area to be identified were Skolt Sami, whose winter villages were located near the Finnish-Norwegian-Russian border in the Paatsjoki River Valley (Alavuotinki, 1999). The number of Skolt Sami people remained small; the population of the main Sami village, Suonikylä, was 160-220 in 1921-1939. Altogether, the number of Petsamo Skolt Sami was 400 in 1939 (Tanner, 1929, pp. 301-304).

After the agreement between the Bolsheviks and Finns in Tartu in October 1920, the Arctic corridor of Petsamo officially became part of Finnish Lapland. The Finnish population of the area in 1921 was just 1500 persons, but by 1944, 5200 persons were registered. The main reasons for the increase were the systemic Finnicization policy, construction of the Rovaniemi-Petsamo road, and opening of the Kolosjoki nickel mine. Petsamo underwent rapid social and economic development. During the 1920 s and 1930s, tourism to Lapland started to grow, mainly because of Petsamo, which many saw as a new Klondike in the High North. The increase in tourism was also due to the opening of the first winter resort areas, skiing huts and wilderness hotels in Lapland (from 1934) (e.g. Lähteenmäki, 2017, pp. 72-87, 162-163). Presidents, politicians, artists, and na-

2 In Kalastajasaarento (Russ. Rybatshi, Sami Giehkirnjárga, No. Fiskerhalvøya) Vaitolahti, Pummanki, Kervanto, and Maattivuono. The other Finnish villages were Liinahamari (harbour), Parkkina, Petsamo, Salmijärvi, Kolosjoki, Höyhenjärvi, Kolttaköngäs, and Nautsi. 
ture enthusiasts from Finland, and in increasing numbers also from abroad, discovered Arctic Petsamo (Hirvelä, 1999). This growth was also stimulated by the government policy of fostering domestic tourism. In this period, the state economically supported the most promising nature tourism areas, Karelia and Lapland. The Finnish authorities promoted political, educational and cultural development in these regions, which they regarded as economically underdeveloped, politically unreliable and culturally non-Finnish (Lähteenmäki, 2012, pp. 45-50).

In 1944, Petsamo was ceded to the USSR and the Finnish population of the area had to be resettled. This loss of the region was tragic for Finland, not least as it meant losing access to the Arctic Ocean. The war from 1939 to 1945 (Tuunainen, 2017; Uola, 2012, pp. 539-544) destroyed Petsamo and entire Lapland so thoroughly that the reconstruction took until the late-1950s to complete. Soviet Pechenga (previously Finnish Petsamo) remained a closed area much longer than the ceded Karelian area, due to the Russian military and industrial sites on the Murman Coast. Furthermore, from the mid-1950s, Arctic Europe increasingly became an arena of tension between the superpowers, as its strategic and economic value steadily increased, and military installations were set up to protect these assets. Petsamo's neighbor, Northern Norway, was also militarized quickly with new garrisons, airports, submarine bases and coastal defenses. On the Soviet side of the border, militarization took more extreme forms, such as nuclear submarine harbors, dozens of garrisons and airfields. All this change influenced the geopolitical importance of Finnish Lapland, resulting in new garrisons being built beyond the Arctic Circle (in Rovaniemi, Sodankylä, and Ivalo) (Elenius et al., 2015, pp. 336-337).

To place the Petsamo tourism in its broader context after the Second World War, we need to introduce some facts about Finnish-Russian cross-border activity. As a Western country, Finland became a pioneer of international tourism to the USSR during the Cold War period (1947-1991). In 1948, the two countries signed the Agreement of Friendship, Cooperation and Mutual Assistance, which opened the borders to selected Finnish tourists. Tours to the socialist empire had bilateral political motives and increased gradually after the death of Stalin (1953) (Orlov, 2014, p. 7). ${ }^{3}$ In the same year, Finnish refugees from pre-war Finnish Karelia had the first opportunity to make nostalgia visits to their former homes. In 1955, an Agreement on Science and Technology between Finland and the USSR was ratified; this included tourism regulations. It is estimated that in 1955, 2500 Finns traveled to the USSR, but by 1966 the numbers had risen to 50,000 . In 1960, the USSR signed a new intergovernmental tourism agreement with Finland and some other Western countries (Orlov, 2014, pp. 14, 16, 21-22).

It has been estimated that in the 1960 s some $95 \%$ of Finns traveling to the USSR participated in planned, standardized tourist packages, programs and sightseeing (Kostiainen, 1998, p. 47; Kostiainen, 1999, p. 34). The most important tourist offices in the USSR were Intourist (founded in 1929) and Sputnik (founded in 1958) (Kozovoi, 2014; Orlov, 2014, pp. 14-15). Their most ac-

3 Tourism to the Soviet Union was popular as early as the 1920s, especially among European left-wing intellectuals. Increasing Western tourism to the USSR led to the foundation of the International Union of Official Travel Organizations in 1925. In return, in 1931 the first 'communist workers' set off on a cruise around Europe; the journey was organized by the Proletarian Tourism and Excursion Society. Although the direction of tourism was mainly from the West to the USSR, the 1920s and 1930s saw the first wave of Soviet tourism. However, this mainly consisted of official delegations of communist or socialist organizations and their leading figures. 
tive Finnish counterparts were Lomamatkat ('holiday tours', founded in 1956) and SN-matkat ('Finland-Soviet Union tours', founded in 1986) which were owned by Finnish socialist-oriented societies.

A new tourism agreement (1974) between the two countries opened more destinations up to Russians, including Lapland (Suomen ja Neuvostoliiton yhteistyöohjelma, 1980). Orlov (2014, p. 27) notes that most Soviet travelers to Finland were 'ecotourists'. They valued Finnish nature, cleanness and well-organized tourist facilities. In 1989, Finns constituted $33 \%$ of all Western travelers to the Soviet Union. The economic importance of Finnish tourists to the USSR was considerable (Inturistissa puhaltavat uudet tuulet, 1989; Juusela, 1984; Kostiainen, 1999, p. 33). Increased international tourism has even been mentioned as a factor contributing to the collapse of the USSR (e.g. Golubev, 2011).

Routes from Finland to the Kola Peninsula were opened by the North Calotte cooperation between the northern parts of Finland, Sweden and Norway. The aim of this activity was to strengthen economic and cultural ties in the European Arctic. One major platform for cooperation were the North Calotte Peace Days festivals, organized from 1964. They strengthened civilian cooperation in the entire North Calotte region. (Elenius et al., 2015, pp. 337-343.)

Although cultural cooperation led to more openness, access to the Petsamo area remained strictly controlled, and it was mostly a closed military region until 1990. Around Liinahamari harbor, Russians built several military installations, such as Sputnik, Km 19, Petsenga and Luostari. Throughout the 1980s the economy of Russian Pechenga was dominated by the nickel mine and the army (Uola, 2012, p. 553). However, Finnish companies (such as Outokumpu Oy, A. Ahlstrom Oy, Rauma-Repola Oy, and Finn-Stroi) often encouraged détente in the Arctic region. A major project was the construction of a nickel and copper smelter in Pechenga in 1974. This was part of the official bilateral Finnish 'East transaction' policy, which combined the political and economic interests of both countries. Economic transnational cooperation was extremely important for the Finnish economy up to the collapse of the Soviet Union (Laakso \& Tamminen, 2014). ${ }^{4}$

\section{Spatiality of nostalgia tourism}

What emotional experiences did Finnish war evacuees face in Russian Pechenga during their first nostalgia tours? On September 1982, a Finnish tourist bus with 40 former inhabitants of Petsamo and their descendants made a trip to Murmansk via the Raja-Jooseppi border crossing (the former Finnish Arctic Ocean Road). The journey was the first in which the return route went through the Petsamo region to Norway. Although the passengers knew that the Petsamo visit was only a transit trip and they could not stay anywhere, their mood was excited. From Murmansk, the passengers boarded a train, which snaked along the Arctic mountains and gulches. Now and then, the train stopped, and Russian passengers boarded or disembarked. Then, they arrived in old Petsamo: they saw the profiles of the familiar fells and reached the village of Luos-

4 The other famous Finnish construction project across the northern border was building the mining town of Kostomuksha in 1977-1985. It was completely constructed by Finnish companies and even the workers came from the Kainuu region of Finland. Today the memorial to President Urho Kekkonen and Alexei Kosygin in the city center reminds tourists of the project. Finns also constructed the Svetogorsk pulp and paper mill from 1972 to 1988. 
tari (literally monastery), en route to Nikel. They had half an hour in the village, where they took their first steps in Petsamo since 1944. This was a very emotional moment. The next stop was in the new part of Russian Pechenga, the mine city of Zapolyarny (built in 1956). There were dead trees and bare soil everywhere, and gray Soviet housing blocks had replaced the functionalist interwar architecture; the entire landscape seemed 'unreal' when they arrived in Nikel. (See Figure 2.) The land around the Kolosjoki miners' community was polluted for kilometers, and the sky was full of smoke and soot. When the former refugees were back in their new Finnish homes, their most intense feeling was deep confusion (Ä̈̈relä, 1982).

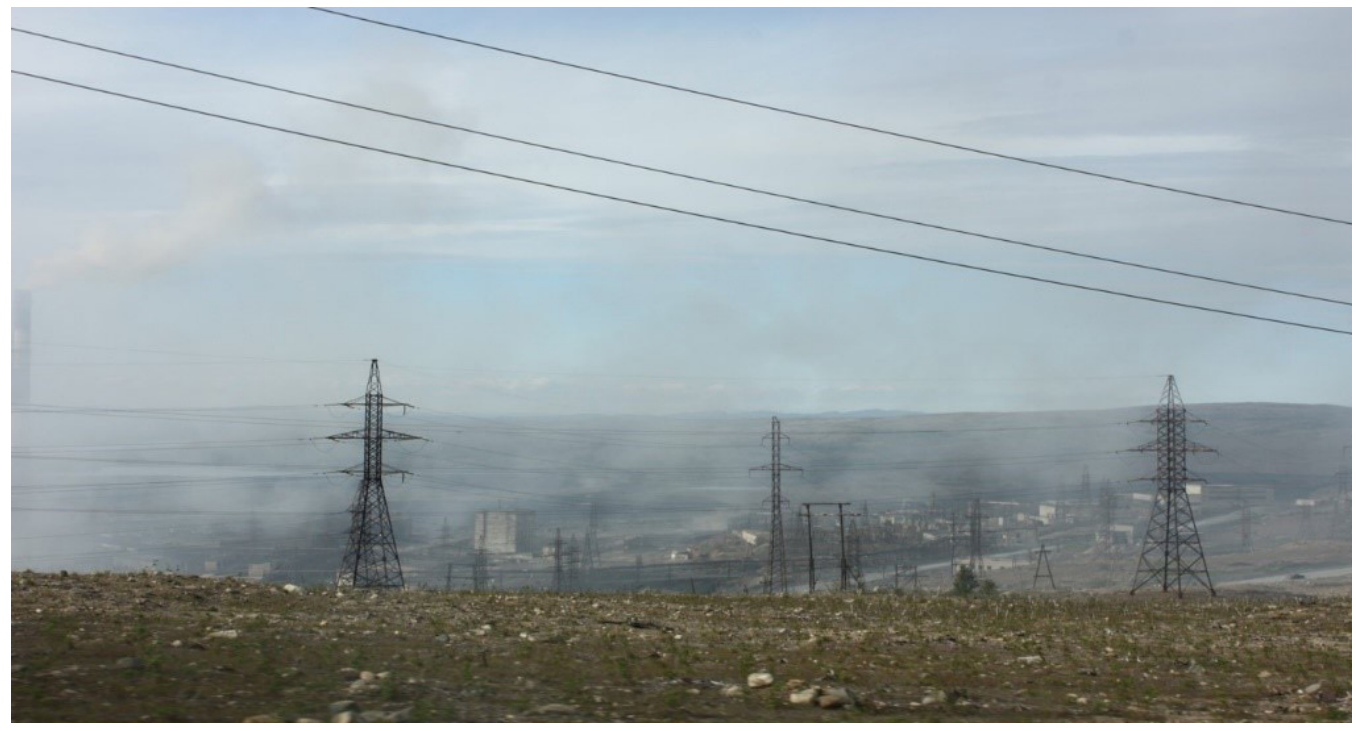

Figure 2. The landscape of Nikel, previously the Finnish village of Kolosjoki. (Photo: Maria Lähteenmäki 2015.)

Memories are spatial in essence (Nora, 1989, p. 12). When Petsamo evacuees finally obtained official permission to visit their former home area in July 1990, they found burned and destroyed land. Not only the villages and graveyards, but also the familiar playgrounds, paths and yards had vanished (Juonala, 2015). As one refugee wrote: 'The Petsamo which we used to know, and which we have in our history books and photos, it does not exist anymore... sometimes I ask myself, did Petsamo exist at all, maybe it was just a dream.' (Kälkäjä, 1982.) How complete the loss had been, how gilded the memories were. Standing in the Arctic landscape, many evacuees called Petsamo a paradise (Kivilinna, 1991) although there were no physical remains of their homes. The former nickel community of Kolosjoki was now the not so attractive Russian town of Nikel, Liinahamari harbor was a closed military zone, and all the larger villages had been destroyed or become Russian communities. The previous village of Parkkina, the administrative center of Petsamo, was now Russian Pechenga with a hammer-and-sickle statue (see Figure 4) and a war monument, the previously lively village of Salmijärvi and the famous Petsamo tourist hotel were destroyed. The old Finnish-Norwegian villages in Kalastajasaarento (Russ. Rybatshi) were burned as well (Sergejeff, 1990). 
In the south-eastern border region of Finland, the situation was totally different. Some Finnish nostalgia tourists who had roots in formerly Finnish parts of Karelia (Border Karelia, Ladoga Karelia and the Karelian Isthmus) were able to visit their old homes in the early 1950s. Some Petsamo refugees were envious of the Karelians for their opportunity to make these journeys: 'Karelians had such a strong esprit de corps and collective sense of Karelianism' (Blomqvist, 1975). The Karelian evacuees also had their own large, strong national organization, the Finnish Karelian League (Karjalan Liitto), which promoted collecting reminiscences and the publication of memory books and histories about their previous home villages and municipalities. In this process, the Karelian evacuees focused on evacuation narratives, remembering the emotionally sensitive forced move from ceded Karelia to inner Finland in the summer of 1944 (Savolainen, 2015).

Due to the political tensions, mass nostalgia tourism to Karelia only took off with the collapse of the USSR. However, it began earlier, in the 1980s, when three new border crossings were planned from Finland (at Niirala, Vartius, and Pelkola) to Russian Karelia. This was the first time when Russian Karelia was named as a destination for Finnish tourists (Kärki-Husu, 1990; Lehmuskallio, 1988; Neuvostoliiton ja Suomen matkailuyhteistyö, 1976). The Petsamo region was not at all advertised or even mentioned in Matkailusilmä, the magazine of the national tourist organization MEK (nowadays Visit Finland) (Volumes of Matkailusilmä in 1976-2015). The only border crossing site in the High North to Murmansk was via Norway, at the Storskog-Borisoglebsk checkpoint (Neuvostoliiton ja Suomen matkailuyhteistyö, 1976). Tourist trips from Finland to Russian Kola Peninsula have been strictly controlled during the decades. 'All uncontrolled movement in the area is forbidden, hunting and fishing are forbidden... all these strict orders distress people of this previously free region.' (Mosorin, 1977). Still in the 2010s, the road checkpoints control traffic in the Petsamo area (see Figure 3).

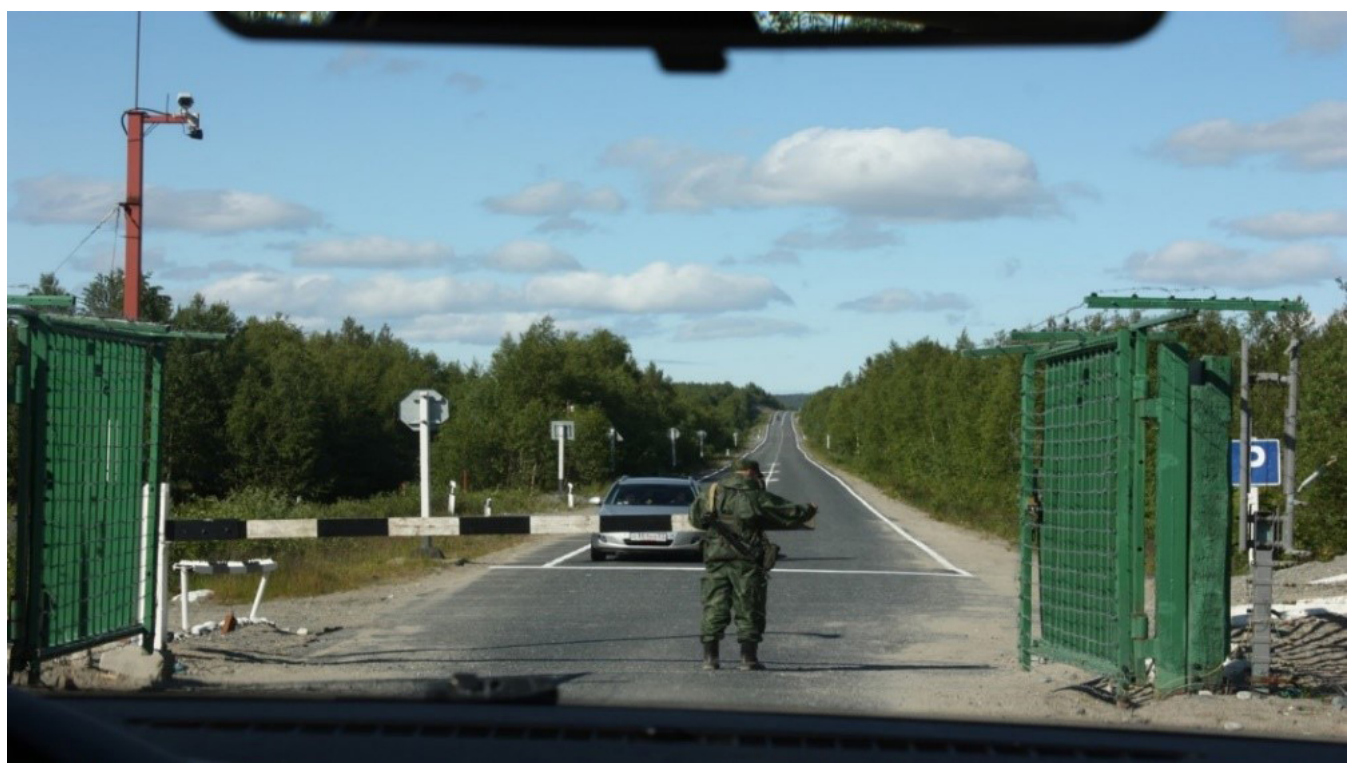

Figure 3. Road checkpoint in Russian Pechenga. (Photo: Maria Lähteenmäki 2015.) 
The concept of tourist is not necessarily correct in terms of the cross-border nostalgia tourism of Petsamo or Karelia. A 'tourist' visits a destination outside his/her usual environment (home) for less than a year for any main purpose (holidays, leisure and recreation, business, health, education or other reasons) (UNWTO, 2010). Although researchers have called them 'nostalgia tourists', at least the first generation, that is, the war refugees, do not consider themselves as tourists, but rather as people visiting their former homes. The Skolt Sami, the indigenous people of the region, were relocated on the Finnish side of the new state border in Sevettijärvi, on the north-eastern shore of Lake Inari. The resettlement region was not far from their previous home area in Petsamo: the landscape is quite similar and is part of the traditional cross-border Skolt Sami homeland. Sevettijärvi village is now the center of the Skolt Sami population in Lapland, and its inhabitants are very active in reshaping their own Orthodox Sami history. Their culture differs in many ways from that of other Sami groups in the European North, and Skolt Sami speakers are in decline (Kulonen, Seurujärvi, \& Pulkkinen, 2005, pp. 395-400).

The Skolt Sami people visited their former homes on the Russian side, too. Skolt Sami evacuee Matti Sverloff has described his journey in 1991 as a meeting of his relatives. Sverloff's home was in Ala-Akkajärvi where the Russians built a copper mine, dammed the nearby river and changed its course just after the war. Due to this extensive construction work, the landscape had changed radically. Sverloff remembered later that 'the wonderful beach of my youth was totally destroyed' and 'there was no life, not even animals in the forest, no moose, no reindeers, no birds'. (Sverloff, 2003, pp. 140, 145; see also Pennanen, 2000). That nostalgia tour was not Sverloff's first trip over the border. He saw the destroyed landscape as early as 1961, when he was working at the Tuuloma hydropower plant construction site built by the Finnish state-owned company Imatran Voima in 1960-1965. Soon after that, he visited Murmansk. The first holes had been made in the Iron Curtain. At the end of the 1980 s the first tours to a couple of places in the Paatsjoki River Valley were organized, and the first snowmobile tour took place in 1991. In 1987, the Nordic Sami Conference was held in Murmansk, marking another important breakthrough in cooperation (Sverloff, 2003, pp. 140-163).

One remark needs to be made here; Petsamo nostalgia tourists are looking for places of memories of their childhoods and families. They seek out the sites of their home villages although these no longer exist, not even on maps. Only some single houses and mossy ruins tell the old Finnish stories, but the first generation remembers the places still and marks them on the maps of their minds, using the old Finnish place names (Lähteenmäki's fieldnotes in the Petsamo fieldtrips in 2014 and 2015). Marschall (2015b, p. 333) has argued that the key driver of war refugees' travel motivation, experiences and performativity is memory, not the physical landscape itself.

In Petsamo memoirs, however, the unique Arctic landscape and nature are important motives for repeatedly organizing nostalgia tours. Ingold (1993, pp. 152, 162-163) has argued that landscape is an experience which connects generations, and that shared stories and myths adhere to landscape. This is true also in terms of Petsamo travel. The Arctic coast is strikingly different and exotic for Finns. This makes Petsamo exceptional, as the resettlement areas in Lapland mostly do not have bare mountaintops or any other features of the Arctic landscape. Most 
Finns from Petsamo were relocated in the uninhabited forested area of Varejoki, which is 70 kilometers southwest of the town of Rovaniemi (see Figure 1).

Refugees of the first generation have written, for instance, that 'everyone felt his/her own smallness there in this great Arctic nature' (Blomqvist, 1976), and 'going to Petsamo, it is a journey to a past landscape' (Soini, 1980). Because the villages had been destroyed, Arctic nature was what awakened old memories (Tolkki, 1992). Barren and beautiful nature itself was the place of memories that refugees missed most in their new homes (Petsamon siirtoväkeä. Radio program, 14/8/1956). Places of memories, according to Nora's (1996) often quoted interpretation, are any places associated with the cult of the dead (here the dead villages and war memories), the national heritage or the presence of the past.
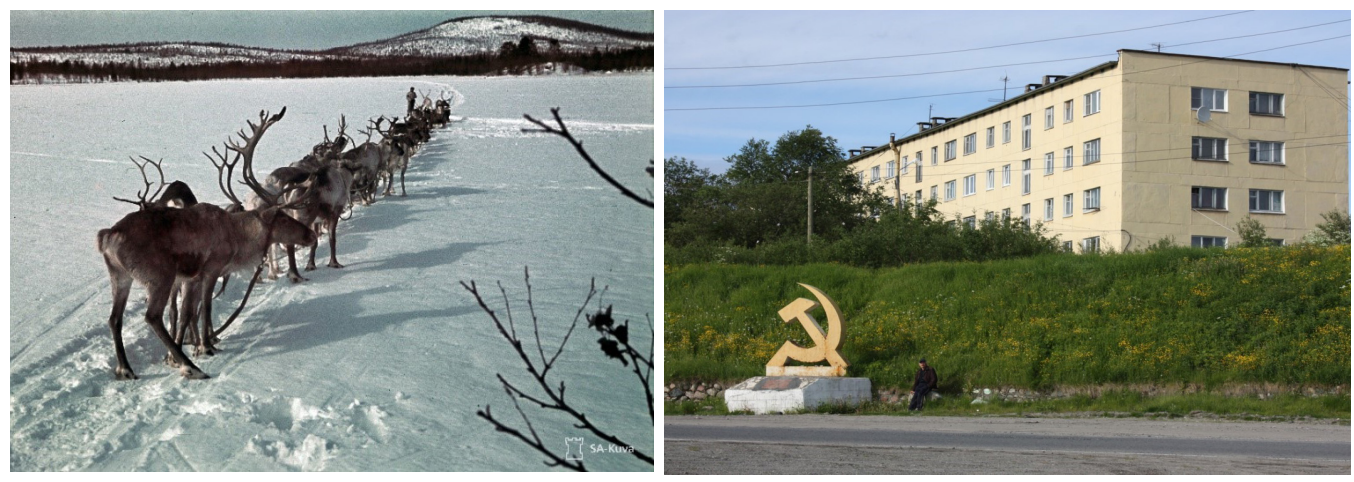

Figure 4. Changing landscapes of Petsamo in 1942 and 2015. (Photo on the left: SA-kuvat/ Finnish Defense Forces 1942. Photo on the right: Maria Lähteenmäki 2015.)

The Petsamo Society has filmed seven tours to Petsamo in 1997-2005 and 2013. In these videos, the main destinations in the area were 1) the ruins of former home villages, individual houses, and the built environment, 2) Second World War battle sites, 3) Russian towns, and 4) sites that were previously closed, such as Liinahamari harbor and Kalastajasaarento (Rybatshi Peninsula) (movies: Our memories: Petsamo 4-7/9/1997; Nikkeli-Petsamo in 1999; On the road in Petsamo 1-5/7/1999; Petsamo 1999; On the road in Petsamo 12-15/6/2002; Petsamo-Murmansk 16-19/6/2005; On the road in Liinahamari 6/7/2013).

The Petsamo evacuees have organized one or two bus journeys to Petsamo almost every year since 1990. Relations with the local Russian people have been quite superficial because of language difficulties and limited time during their visits (usually lasting three to five days). During the first official journey to Pechenga in the summer of 1990, locals stopped the bus and offered vodka and pickled cucumbers: they were eager to talk and get to know the former inhabitants of the region (Sergejeff, 1990, p. 49): having the same home area connected people (Lehto \& Timonen, 1993). 
Nostalgia tourists usually overnighted in hotels in the town of Zapolyarny, some 25 kilometers east of Nikel, which has about 16,000 inhabitants. During the tours, Finns employed local guides and ordered picnics, especially when visiting Liinahamari harbor and the Rybatshi Peninsula, which opened to Finnish tourists as late as the 2010s. Thus, local entrepreneurs who benefit from nostalgia tourism were and still are mainly hotels, shopkeepers and locals who take tourists to the closed villages (Isotupa, 2012). The nostalgia tourists also met leading figures of the town of Nikel, had official dinners with their cooperation partners, and exchanged gifts and friendship speeches, as was done on previous friendship tours (movies: Our memories: Petsamo 4-7/9/1997; Nikkeli-Petsamo in 1999; On the road in Petsamo 1-5/7/1999; Petsamo 1999; On the road in Petsamo 12-15/6/2002; Petsamo-Murmansk 16-19/6/2005; On the road in Liinahamari 6/7/2013).

Although Finnish nature tourists also visit Russian Pechenga today, compared to Karelia the number of travelers are quite small. Karelian cross-border nostalgia tourism is well organized. The Finnish Karelian League was established in 1940, and in 1948, the first local nostalgia associations of Finnish refugees (Finn. pitäjäseurat) were established. There are some 400 Karelian associations headed by former refugees or their offspring in Finland today. Almost every society has at least one nostalgia tour to the ceded areas every summer (Karjalan liitto homepage, 2018). As researchers have shown, tourism is centered on the fundamental principles of exchange between peoples and is both an expression and experience of culture. Tourism is cultural, and as such, it plays a vital part in helping us understand both ourselves and the multi-layered relationships between humanity and the material and non-material world we occupy and journey through (Tazim \& Robinson, 2009, p. 4). Nostalgia tourists have their own small part to play in marking places and keeping Finnish Petsamo alive. From this point of view, nostalgia tourism in both Petsamo and Karelia can be seen as a political act.

\section{Written data: changing views of Petsamo}

\section{Results of the Petsamo corpus}

The number of public writings in our Petsamo corpus varied by publishing year (Table 1). The variation in year of publication tells us much about Finns' interest in lost Petsamo. In a broader context, however, Petsamo tourism opens many windows onto Finnish-Russian relations during the period of the Cold War.

It is evident from the table that the number of publications gradually began to increase, picking up pace in the 1960s and 1970s, and peaking in the 1980s and 1990s. The period after 2000 seems stable, although slightly less active than the 1990s. 
Table 1. Number and share of articles related to Petsamo published in Finnish newspapers and magazines, 1945-2015. ${ }^{5}$

\begin{tabular}{lcc} 
Period & number & $\%$ \\
\hline $1945-1954$ & 6 & 1 \\
\hline $1955-1964$ & 7 & 7 \\
\hline $1965-1974$ & 52 & 11 \\
\hline $1975-1984$ & 52 & 11 \\
\hline $1985-1994$ & 132 & 29 \\
\hline $1995-2004$ & 96 & 21 \\
\hline $2005-2014$ & 94 & 20 \\
\hline 2015 & 24 & 5 \\
\hline Sum total & 463 & 100 \\
\hline
\end{tabular}

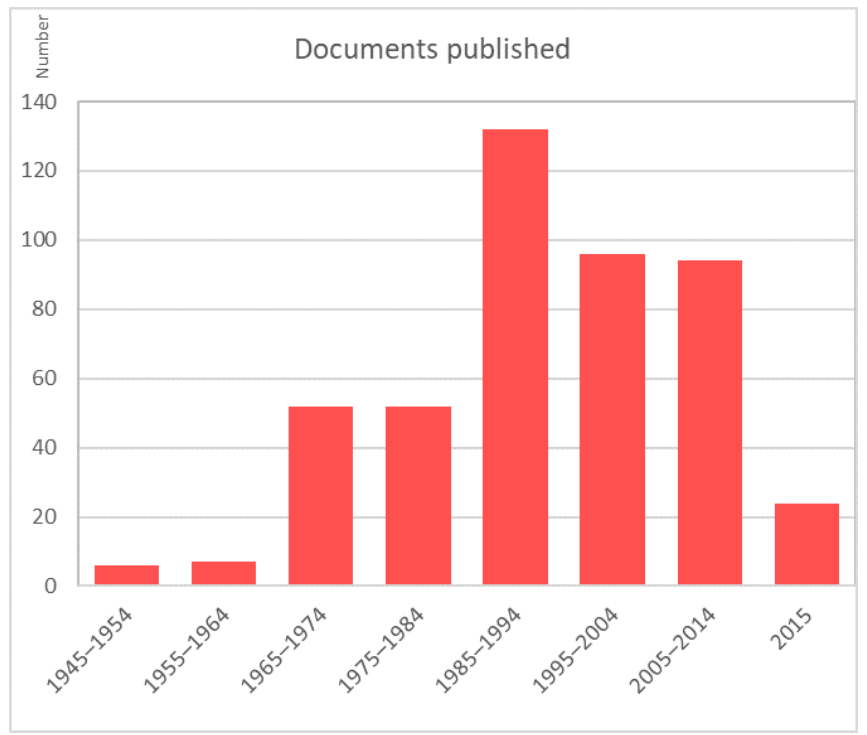

Despite the limited amount of data, the first ten years (1945-1954) after the war are interesting (see Figure 5a). The two most frequent words in the first decade were Germany's (indicates German possession, Finn. saksalaisten) and Germans (Finn. saksalaiset). After these come the terms against (vastaan), Liinahamari (main harbor, place name), Russians (venäläiset), Norway's (Norjan), enemy's (vihollisen), Finland's (Suomen), and navy unit's (meriosaston). All the words are related to warfare in 1941-1944 when German troops were present in Northern Norway as an occupier, and in northern Finland as an ally. Petsamo was one of the Germans' most important stations in this period. Due to the dramatic turn in the conflict, German troops fought against the Finns, who signed a peace treaty with the Soviet Union in September 1944, from that point until February 1945 (called the Lapland War). Interestingly the bombing of Petsamo and Liinahamari harbor by British naval forces in July 1941, four months before Britain officially declared war, is not mentioned at all in our corpus. One female witness does mention this event in the video documents, remembering it from when she was a young girl in Petsamo (movie, Our memories: Petsamo 4-7/9/1997). The local population were not evacuated until the Lapland War started, that is, in September 1944 .

5 FINNA database 1945-2015; Helsingin Sanomat 1990-2015. 
a) $1945-1954$

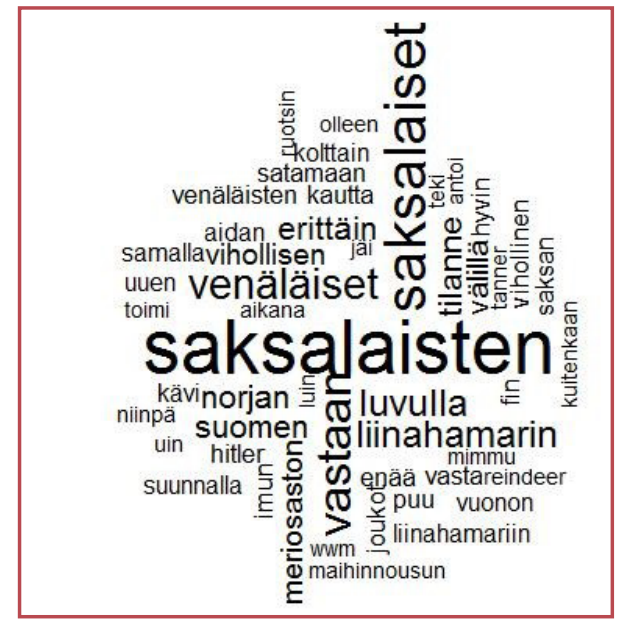

1. saksalaisten=Germans'

2. saksalaiset=Germans

3. venäläiset=Russians

4. vastaan=against

5. Liinahamarin=Liinahamari harbour's

6. Norjan=Norway's

7. Suomen=Finland's

8. meriosasto=naval department

9.vihollisen=enemy's

10. välillä=between b) $1994-2004$

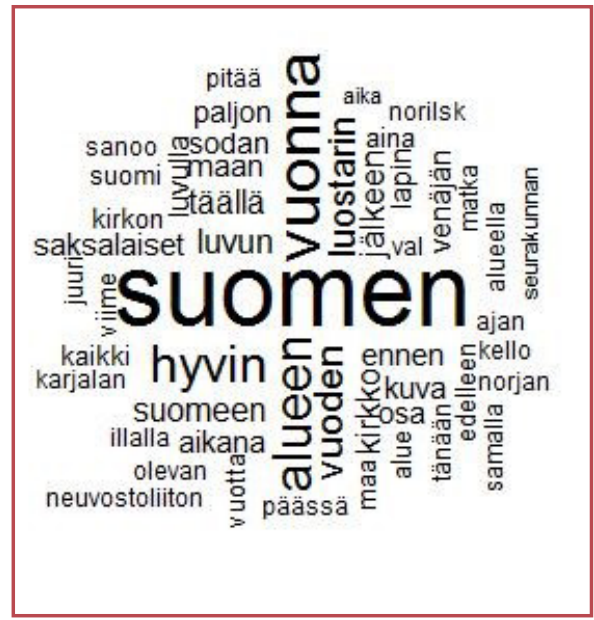

\section{Suomen=Finland's \\ 2. vuonna=in the year \\ 3. alueen=region's \\ 4. hyvin=well}

5. luostarin=monastery's

6. kirkko=church

7. jälkeen=after

8. Suomeen=to Finland

9. sodan=war's

10. kuva=picture

Figure 5. The word clouds of the most common terms a) in 1945-1954 and b) in 1995-2004.

The next two decades, the 1980 and especially the 1990s, show a gradual change, as the first nostalgia tours were organized. Words related to religious sites (monastery and church) appear, as well as words referring to the nickel mine. Also, terms related to nature are found, most frequently the Arctic Ocean and rivers. The articles underlined the Finnish heritage and ownership of the region: the most common term was Finland's (Suomen). The terms in the year (vuonna, vuoden), region (alue), before (ennen), during (aikana), and after (jälkeen) convey the temporal dimensions of the public memory writings. During the next decade - in a quite remarkable way - the Finnish nostalgia tourists and press were also interested in the church (kirkko) and the Orthodox monastery (luostari) in Petsamo (Figure 5b). The Skolt Sami people are mostly Orthodox, and Finns mainly Lutheran. This was also the era of the post-collapse Soviet Union that in general demarcates the interest in Orthodoxy. Looking at the texts, however, it seems that this was the period when Petsamo was most likely to be interpreted as a purely Finnish region. The earlier Finnish possession of Petsamo was the master narrative of the era, when history began to be rewritten in a process 
of regional identification with a unique 'Finnish Petsamo'. However, the severe pollution in the Kola Peninsula, the gray mines and mining towns, and even nature itself, were not reflected in the texts as we had expected.

After 2005 there seems to be a shift toward 'softer' topics, such as children, weddings and land. There were sporadic references to Karelia, probably reflecting the different level of access to their former homes. Interestingly, references to geographical locations is limited to Helsinki, Oulu and Inari, as well as some places in Petsamo, Luostari and Kolosjoki (Nikel). Although the Finnish Petsamo narrative is clearly being constructed, at the end of the period there is a sense of acceptance: the terms Russia and Russian clearly dominate over Finland and Finnish.

The third word cloud (2015, Figure 6) gives the references to 'Finnish Petsamo' a new dimension. The year 2015 was the last period included to our data. The term Russia's (Finn. Venäjän) is almost as frequent as Finland's (Suomen) Petsamo. This is the first time when this kind of Russia-oriented counter-narrative appeared in public memory of Petsamo. According to Bamberg and Andrews (2004) counter-narrative does not contrast with, but supports master narrative. They both create individual identities in respect of each other. The picture of Petsamo is becoming richer and more varied during 2015. During the 2010 s it had become possible to write more openly about sensitive issues, such as the experiences of prisoners of war interned by the German troops in the High North, and the cruel fate of border villages such as Alakurtti, which was originally a small Finnish village, during the war a German military base, and afterwards a Russian military garrison (e.g. Blomqvist, 2013; Isotupa, 2014; Kunnari, 2013; Rantala, 2013; Rantala, 2014).
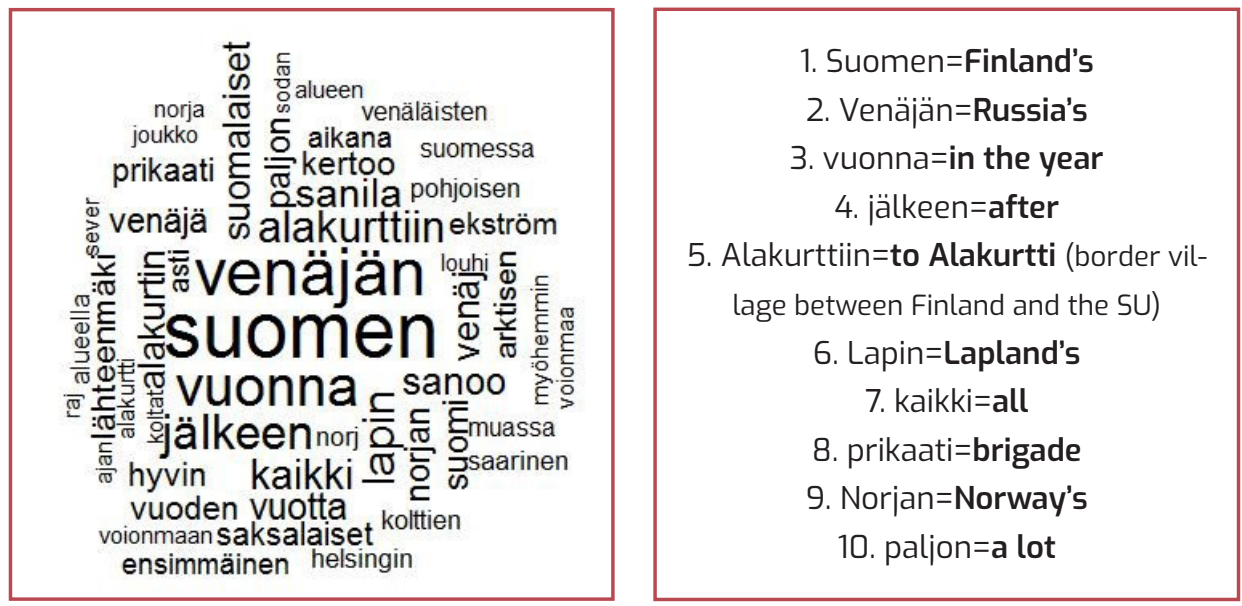

Figure 6. The word clouds of the most common terms in 2015.

\section{Results of the NGO corpus}

The NGO corpus (the texts of Petsamolaista magazine published by the Petsamo Society) is quite different from the previous material. The number of relevant writings is quite stable over the decades, about ten per year, with a maximum of 29 in the period 2004-2014. In the 1970s, there is an absence of references to the war period. This notion resonates both with the Petsamo peo- 
ple's purpose to avoid painful memories of the tragic and traumatic experiences. This reflects the general trend in Europe during the 1970s anti-war movement.

For the following decade, 1975-1984, the corpus contains few geographical references, except to the Arctic Ocean, Lapland, shoreline and land, in addition to more general descriptive terms such as life, road, own, place and children. In the next decade, 1985-1995, the most frequent word is society (it is, Petsamo-Seura) as this is the driving force and social forum for the evacuee community. Thereafter there are references to the land, Norway, Arctic Ocean, sea, ford, village, the company (nickel mining company), Lapland, and river. The narrative seems to contain stories and general descriptions, not factual historical events. Interesting notion is that the hegemonic talk about the Arctic nature underline the importance of landscape for the Petsamo nostalgia tourists. The third period, 1995-2004, clearly reflects the gradually dwindling numbers of Petsamo refugees. The most frequent terms are all related to the society: societies, chairperson, members, the magazine, history, book (on Petsamo history) and university, as well as some names of Finnish historians writing the history of Petsamo. The academic history of Petsamo published in 1999 was a remarkable achievement for the small Petsamo Society.

In the last decade, 2005-2014, the recurring words in the NGO corpus are the society, board (of the society), as well as land, church, father and my father. This indicates the increasing importance of second generations, and of the Petsamo Society. Here we also find the only mention of the word war, as if the refugees actively want to forget the war period, and only remember the 'lost paradise'. The only season referred to is summer, as if there was no winter, another hint at glorification of the past. Surprisingly, there are few words relating to Sami people. This illustrates the fact that the two ethnic communities, the larger Finnish and the tiny Skolt Sami, have separate languages and social identities, and were resettled in different areas.

\section{Public reminiscence: books and monuments}

The process of reminiscence connected with nostalgia tourism of the Petsamo people was expressed through various activities, including annual meetings, and remaking old symbols of the region, such as a coat of arms, stamps, memorial plates and the Polar Tour badge. The Petsamo Society has actively supported and revitalized history projects and collected oral memories and photographs of the region, and it has its own homepage (Kunnari, 2015). Mostly the makers of the memory politics in the late 1990 s belong to the second generation. The society's largest project was commissioning professional historians to write a book, Turjanmeren maa, Petsamon historia 1920-1944 (The Land of the Arctic Ocean: A History of Petsamo, 1920-1944, edited by J. Vahtola \& S. Onnela), published in 1999. The history project received financial support from twenty societies and many private individuals (Vahtola \& Onnela, 1999, p. 4). Another, much smaller history booklet was published in 2012, when the Petsamo Society celebrated its fortieth anniversary (Kälkäjä, 2012). All these public memory acts stressed that collective history and cultural heritage is the power that keeps these small communities of the Arctic region alive (Savukoski, 1993).

Even before that, the first generation had been active: as early as 1979, the evacuees reminded themselves that their most important task was collecting memories for future generations 
(Mosorin, 1979, p. 3). They realized, however, that it could be difficult to paint a 'real' picture of Petsamo due to 'all the gold rain which has fallen on our childhood memories' (Ananin, 1979, p. 5). To share their collective experiences and strengthen their identity, the Petsamo Society launched a memory-collecting contest in 1976, and published the memories in Petsamolaista. Most of the published stories are reflections on the link between childhood memories and current experiences (On reflexive narration, Savolainen, 2015, pp. 112-115). The identification process included publishing their own dance, the Petsamo waltz, a Petsamo song and poems (Kivilinna, 1976; Petsamon laulu, 1978).

One important but unsuccessful public memory project was the Petsamo monument initiative. Marschall (2010, p. 3) has stressed that public monuments constitute discursive formations that pose a direct response and challenge to hegemonic discourses and contested ideologies and are important mechanisms in the project of reshaping public memory and rewriting the past. In 1977 some first generation Petsamo activists participated in the ceremony during which the Kven monument was unveiled in Vesisaari (Vads $\varnothing$ in Northern Norway) to honor the Finns who moved to Northern Norway in a much earlier age, mostly in the nineteenth century. 'When we looked at the Kven statue, it aroused powerful feelings of our homesickness for Petsamo' (Mosorin, 1977).

The Petsamo evacuees repeatedly sought permission from the Murmansk authorities to unveil a monument in Russian Pechenga, but were refused time after time, which increased their feelings of bitterness. Even the Germans were granted the right to unveil a monument in Pechenga in honor of their fallen soldiers. But the Finns found it difficult to erect any public monument in Petsamo, unlike the Karelian refugees who had erected hundreds of memorials, mainly in graveyards, in the ceded parts of Karelia. Finally, in 1997, the club of the Lapland Border Guard was permitted to unveil a memorial stone on what used to be the Finnish-Soviet Union state border (movie, Our memories: Petsamo 4-7/9/1997). All this resistance indicates that the Russian Arctic remains a strongly militarized area, and that Russia wants it to retain a purely Russian history and regional identity.

After ten years of trying to get the statue to Petsamo, the society decided to erect the memorial on the Finnish side. Thus, the Petsamo monument 'The evacuee road of the people of the Arctic Ocean' was commissioned from the famous Finnish sculptor Ensio Seppänen, who also created the Kven statue, and erected in 1985 in Ivalo, Finnish Lapland. The monument presents four types of inhabitants of the area: a fisherman, a miner, a Skolt Lapp woman with a baby and a worker with a spade. Its unveiling was a very emotional moment. 'Love of homeland is the strongest emotion of a human being: it follows him/her through life, and everywhere' (Mosorin, 1984). The Ivalo monument was the most visible heritage from the first Petsamo generation to their offspring, but it has also national, even transnational, focus: it was a cultural manifest and reminder of the legacy of the Arctic borderland to all Finnish people.

The second generation of Petsamo evacuees continue their efforts to preserve a public memory. The other Petsamo monument was unveiled in 1997 in the Arctic Museum, Rovaniemi. It was created in honor of the fallen soldiers from Petsamo. In 2005 the statue in memory of civilian war victims of Petsamo was erected in the village of Nellim, near the border with Finland 
and Norway. Finnish nostalgia tourists often visit the monolith in the middle of the town of Nikel: Finns know very well that it was originally 'the independence statue of Petsamo', a stone erected in 1939 'on the authentic site where the Finnish flag was hoisted for first time in this region' (Petsamon itsenäisyyspatsas, 1939). The Petsamo Society's most recent memorial project was the reconstruction of the destroyed Petsamo bell tower, originally built in 1906-1908. It was inaugurated in the summer of 2016 in Varejoki (see Figure 1), where the largest number of Petsamo war evacuees were relocated (A new monument, 2018).

The identification process has not been easy due to the multicultural background of the Petsamo people. Most of the 5200 evacuees were Finns (including some Karelians from the village of Trifona, between Parkkina and Liinahamari) and 400 were Skolt Sami. The Petsamo Society advocated cooperation between ethnically Finnish and Skolt Sami refugees, but due to 'the bad road connections and destitution', the efforts were not successful. From the 1970s onward the Skolts formed closer ties with the Nordic and later international Sami community. The other refugees were further divided along political lines in the 1950s, with separate societies for leftand right-wing members (Melamies, 2017, pp. 85, 87).

The emotional experiences of Petsamo war refugees are part of a global phenomenon. It has been estimated that 80 million people were displaced in 1940-1960 because of the Second World War (e.g. DePillis, Saluja, \& Lu, 2015; Shephard, 2011). Phillips and Reyes (2011) have introduced the term global memoryscapes to indicate the complex dynamics that influence and alter memories and memory practices within and across local, national, and transnational registers. They aim to move beyond considering the processes of public memory purely in relation to local or national cultures, and instead seek to resituate memory within a global framework. For Phillips and Reyes, global memoryscapes are a concept for imagining the ways that global forces affect local memories, international encounters create and transform memories, and memories change and adapt as they move across the global landscape. Houdek and Phillips (2017) have argued that such a conceptual shift aids in the ability to foster a 'global memory horizon' and 'planetary community' that would be able to respond better to universal crises and craft global perspectives in general. An increasingly shared global memory of events has contributed to a growing transnational human rights movement.

\section{Conclusions: collective manifestations of acceptance}

Finland was a pioneer in Soviet tourism during the Cold War period, but this was true mainly in terms of south-eastern Finland and the large metropoles and holiday resort areas in the Soviet Union. Gradually, from 1948, many bilateral economic and science agreements and the North Calotte cooperation between Finland and the USSR paved the way for growing cross-border tourism, but the Arctic Petsamo region remained closed until 1990. To counter this, Finnish industry played a surprisingly important role in drawing back the Iron Curtain, especially through the construction of power plants and other infrastructure in the borderland of the north-western Soviet Union in the 1960s-1970s, also in the Arctic border region. 
According to the Petsamo corpus, Petsamo's role in the nostalgia discourses of ceded areas was peripheral compared to that of Karelia. As one reminiscent wrote, 'Petsamo has been like a foreign country for Finland, and now it is a land of memories for Petsamo evacuees' (Arrela, 1981). The Lappish municipality of Salla, which had to cede half of its territory to the Soviet Union, is a similar case. The hegemonic discourse about lost Karelia have overshadowed other ceded Finnish regions, and the Arctic evacuees have often been forgotten. The North has not been officially recognized in Finland in the same way as the East.

The Petsamo evacuees consist of Finnish settlers, and a distinct indigenous Skolt Sami people, who identified with their transnational cultural region, called Sápmi (the northernmost areas of Finland, Sweden, Norway and Russia) from the 1970s. They were integrated into the larger Sami ethnic and empowerment movement, which gained momentum from the 1980s. At the same time, the Petsamo Finns established their own societies and magazines and started to strengthen their Petsamo evacuee identity. The two ethnic groups, Finns and Sami, could not find a common voice on shared issues, but separated into distinct communities of memory. They were even resettled far apart, nearly 600 kilometers away from each other. This weakened the identity-building process of the Petsamo evacuees and their descendants.

The Finnish resettled population of Petsamo integrated into the majority society, and as a result the two ethnic communities soon grew apart. Probably their only common experience was of evacuation from their former homes. It appears that the forced move was more traumatic for the Finns who were resettled far away in a place very different from their earlier home in terms of nature and landscape. The Finns interpreted and highlighted the Petsamo people and their identity as nationally Finnish but at the same time a unique Arctic kin different from southern Finnish people: 'Petsamo people are special among Finnish evacuees' (Soini, 1983). The Petsamo corpora, however, indicate that Petsamo has had, and still has a special place in the Finnish national historiography and national imagery due to its exotic Arctic character.

The first and second generations of Petsamo memory makers used some similar means in their memory politics. In the 1970s-80s the key focus of the first Petsamo generation was on institutional and practical work: they put a lot of effort to establish their own societies, and newspaper. In addition, they focused on relocation, reconstruction and war damage compensation challenges, that is, on material issues. Much of their everyday life and energy went into clearing fields, building new homes and farms, but in the 1970s and 1980s - when the common ethnic movement awoke - also Petsamo people activated in their reminiscence work (oral history collection, Ivalo monument). In their public memories, they reconstructed the imagined villages of childhood and considered Petsamo above all as an emotional community, a basis for collective identity building.

From the 1990s, after the collapse of the Soviet Union, the second and third generations from Petsamo focused more than their parents on immaterial cultural heritage, natural heritage and the multi-ethnic past of the region. The big change in their memory politics occurred when Petsamo opened up to nostalgia tourism. The imagined Petsamo was now real, not only a lost paradise or grayscale photos in mother's album. After the nostalgia tourists had experienced the shock of the devastated landscape, their image of Petsamo became more realistic; the 
visitors realized that there was no return to the past. They did not abandon their ravaged home areas, however, but looked at the landscape, mountains, waters and sky with new eyes, from a multisensory and selective perspective. Since their villages had been destroyed almost completely, the Petsamo people related their memories more than ever to the landscape and Arctic nature. Physical attachments (ruins, rivers, individual houses, movies, and photographs) recall and demonstrate their collective and intergenerational experiences of Petsamo. Our source material underlines the fact that historical texts and acts always reflect the time, space and culture in which they have been produced.

In conclusion, the multilevel politics of memory including nostalgia activities of the Petsamo people, in the first, second and third generations, writing publicly in national newspapers and magazines, can be interpreted as part of a collective, also national, process of surrender and sorrow. The discussions were both therapeutic and emotional, but also express surprisingly strong communal empowerment and new developments. The process of mental differentiation and distancing from their former homes of Petsamo started when the evacuees and their offspring saw the landscape of their or their parents' childhood polluted in the early 1990s. The Petsamo people and their descendants emotionally accepted the loss of their homeland at the latest in the 2010s: Petsamo become an immaterial space of northern Finnish heritage, culture and history. Also, the geohistorical image of Petsamo changed. From the late 1960s to the early 2010s Finnish was the most often used word in the Petsamo corpora, but the year 2015 saw a turn toward more multicultural interpretations, when texts considered the Russian Pechenga, Orthodox monasteries and religion.

All in all, in the case of lost Petsamo, the Finnish post-war politics of memory took many forms: nostalgia tours, shared reminiscence, history books, monuments, and public writings. This politics of memory tells us a lot about the transformed relationship and opened borders between Finland and the Soviet Union, later Russia. As part of that, the retold story of Petsamo gives a more holistic picture about how both Russia and the Western democracies have re-evaluated the European Arctic after the war, its natural resources, and its historical and cultural heritage.

\section{References}

\section{Literature}

Alavuotinki, J. (1999). Petsamon historia yhteisalueen jaosta ensimmäiseen maailmansotaan.

In J. Vahtola \& S. Onnela (Eds.), Turjanmeren maa: Petsamon historia 1920-1944 (pp. 35-45).

Rovaniemi: Petsamo-seura.

Ananin, H. (1979). Muistikuvia kotiseudulta. Petsamolaista, 5.

A new monument (2018). Petsamo Society's homepage. Retrieved from https://www.petsamoseura.net/alaluostarin-kellotapulin-nakoisversio

Armstrong, K. (2004). Remembering Karelia: A family's story of displacement during and after the Finnish Wars. New York: Berghahn Books. 
Arrela, V. (1981). Muisteluksia menetetystä Petsamosta. Petsamolaista, 19.

Baker, A. (2003). Geography and history: Bridging the divide. Cambridge University Press.

Bamberg, M., \& Andrews, M. (Eds.) (2004). Considering counter-narratives: Narrating, resisting, making sense. Amsterdam: John Benjamins Publishing.

Berry, M. W. , \& Kogan, J. (Eds.) (2010). Text mining: Applications and theory. Chichester: Wiley.

Blomqvist, L. (1975). Puheenjohtajan tervehdys. Petsamolaista, 3.

Blomqvist, L. (1976). Puheenjohtajan tervehdys. Petsamolaista, 3.

Blomqvist, M. (2013). Juuria etsimässä: Matka Petsamoon 12.-14.7.2013. Petsamolaista, 14-21.

Boym, S. (2001). The futures of nostalgia. New York: Basic.

Burdick, J., Drucker, P. Lunenfeld, T., Presner, T., \& Schnapp, C. (2011). Digital humanities. Cambridge MA: MIT Press.

DePillis, L., Saluja, K., \& Lu, D. (2015). A visual guide to 75 years of major refugee crises around the world. The Washington Post, December 21. Retrieved from https://www.washingtonpost. com/graphics/world/historical-migrant-crisis/

Elenius, L., Tjelmeland, H., Lähteenmäki, M., \& Golubev, A. (Eds.) (2015). The Barents region: A transnational history of subarctic Northern Europe. Oslo: PAX.

Feinerer, I. , \& Hornik, K. (2017). Tm: Text mining package. R package version 0.7-3. Retrieved from https://CRAN.R-project.org/package=tm

Fellows, I. (2014). Wordcloud: Word clouds. R package version 2.5. Retrieved from https:// CRAN.R-project.org/package=wordcloud

Gold, M. K. (Ed.) (2012). Debates in digital humanities. University of Minnesota Press. Retrieved from http://dhdebates.gc. cuny.edu/book/2

Golubev, A. (2011). Neuvostoturismin ja läntisen kulutuskulttuurin kohtaaminen Suomessa. Historiallinen Aikakauskirja, 109, 413-425.

Guest, G., MacQueen, K., \& Namey, E. E. (2012). Applied thematic analysis. Thousand Oaks, California: SAGE.

Halbwachs, M. (1992). On collective memory. Chicago University Press. (Original work published 1952.)

Hirsch, M. (2012). The generation of postmemory: Writing and visual culture after the Holocaust. New York: Columbia University Press.

Hirvelä, A. (1999). Petsamon matkailu. In J. Vahtola \& S. Onnela (Eds.), Turjanmeren maa: Petsamon historia 1920-1944 (pp. 329-346). Rovaniemi: Petsamo-seura.

Houdek, M. , \& Phillips, K. (2017). Public memory. Retrieved from https://oxfordre.com/communication/view/10.1093/acrefore/9780190228613.001.0001/acrefore-9780190228613-e-181 
Ingold, T. (1993). The temporality of the landscape. World Archaeology, 25(2), 152-163.

Inturistissa puhaltavat uudet tuulet (1989). Matkailusilmä, 3/1989, 8.

Isotupa, L. (2012). Muistoja ensimmäiseltä matkaltani lapsuuden kotikylääni. Petsamolaista, $38-45$.

Isotupa, L. (2014). Terveisiä Liinahamarista. Petsamolaista, 18-23.

Juonala, J. (2015). Petsamon evakko: Pohjoisen elämästä oli romantiikka kaukana. Ilta-Sanomat, 9/12/2015.

Juusela, J. (1984). Suomen ja Neuvostoliiton matkailun kasvu tilastojen valossa. Matkailusilmä, 1/1984, 19-21.

Karjalan liitto [The Karelian League] homepage (2018). Retrieved from https://www.karjalanliitto.fi/karjalan-liitto/jasenyhteisot.html

Kivilinna, R. (1976). Muistot talteen. Petsamolaista, 16-17, 23.

Kivilinna, R. (1991). Se oli paratiisi. Petsamolaista, 7.

Kostiainen, A. (1998). Mass tourism, groups and delegates: Travel from Finland to the Soviet Union from 1950 to 1980. In A. Peltonen \& M. Heikkinen-Rummukainen \& (Eds.), Trends in Russian research on tourism: International forum for tourism research, No. 3 (pp. 46-50). Savonlinna: The Finnish university network for tourism studies.

Kostiainen, A. (1999). The vodka trail: Finnish travellers' motivation to visit the former Soviet Union. In T. Toivonen \& J. Ahtonen (Eds.), Travel patterns: Past and present (p. 33-48). (Discussion and working papers series 1.) Savonlinna: The Finnish university network for tourism.

Kozovoi, A. (2014). The way to a man's heart: How the Soviet travel agency 'Sputnik' struggled to feed Western tourists. Journal of Tourism History, 6, 57-73. https://doi.org/10.1080/175518 2X.2014.956809

Krosby, H. P. (1967). Petsamo in the spotlight: A study in Finnish-German relations, 1940-1941. New York: Columbia University.

Kulonen, U.-M., Seurujärvi I., \& Pulkkinen, R. (Eds.) (2005). The Saami: A cultural encyclopaedia. Helsinki: Finnish Literature Society.

Kunnari, T. (2013). Käyntimme Liinahamarissa. Petsamolaista, 22-23.

Kunnari, T. (2015). Petsamo-seura historiatyössä, Petsamolaista, 8-9.

Kuusikko, K. (1996). Laiton Lappi, laiton Petsamo: Rikollisuus ja järjestysvalta Petsamossa 1921-1944. University of Oulu.

Kälkäjä, M. (1982). Petsamolaisuus. Petsamolaista, 5-8.

Kälkäjä M. (Ed.) (2012). Petsamo-Seura Ry. 40 vuotta 1972-2012. Tornion Kirjapaino.

Kärki-Husu, S. (1990). Neuvosto-Karjala avautuu turisteille. Matkailusilmä, 1/1990, 14. 
Laakso, M., \& Tamminen, S. (Eds.) (2014). Rakentajat maailmalla: Vientirakentamisen vuosikymmenet. Helsinki: RIL.

Lehmuskallio, T. (1988). Perestroika Neuvostoliiton ulkomaanmatkailussa. Matkailusilmä, 3/1988, 15 .

Lehto, L., \& Timonen, S. (1993). Kertomus matkasta kotiin: Karjalaiset vieraina omilla maillaan. In P. Laaksonen \& S.-L. Mettomäki (Eds.), Kauas on pitkä matka (pp. 99-102). (Kalevalaseuran vuosikirja 72). Helsinki: Suomalaisen Kirjallisuuden Seura.

Lähteenmäki, M. (2012). The making of the border between two worlds: The struggle over Finnicization of the border region between Finland and Russia in the 1910s and 1920s. Eurasia Border Review, 3(1), 33-50.

Lähteenmäki, M. (2016). The struggle for political space: A geohistory of public monuments in the Finnish town of Vyborg. In K. Katajala (Ed.), Meanings of an urban space: Understanding the historical layers of Vyborg (pp. 179-180). Zürich: LIT.

Lähteenmäki, M. (2017). Footprints in the snow: The long history of Arctic Finland. (Prime Minister's Office Publications, 12/2017). Helsinki. Retrieved from https:/julkaisut.valtioneuvosto.fi/ bitstream/handle/10024/80043/VNK_J1217_Footprints\%20in\%20the\%20snow_net.pdf?sequence $=1$

Marschall, S. (2010). Landscape of memory: Commemorative monuments, memorials and public statuary in post-apartheid South Africa. Leiden: Brill.

Marschall, S. (2015a). 'Homesick tourism': Memory, identity and (be)longing. Current Issues in Tourism, 18, 876-892. https://doi.org/10.1080/13683500.2014.920773

Marschall, S. (2015b). Touring memories of the erased city: Memory, tourism and notions of 'home'. Tourism Geographies, 17, 332-349. https://doi.org/10.1080/14616688.2014.1000957

Maurantonio, N. (2014). The politics of memory. In K. Kenski \& K. Hall (Eds.), Oxford handbook of political communication. Oxford University Press. https://doi.org/10.1093/oxfordhb/9780199793471.013.026

Melamies, M. (2017). Petsamolaisten etujärjestötoiminta Suomessa 1944-1953. Pro gradu -tutkielma, Oulun yliopisto, Historia. Retrieved from http://jultika.oulu.fi/files/nbnfioulu-201706012354.pdf

Mone, G. (2016). What's next for digital humanities? Communications of the ACM, 59(6), 20-21. https://doi.org/10.1145/2911973

Mosorin Y. (1977). Puheenjohtajan tervehdys. Petsamolaista, 5.

Mosorin, Y. (1979). Puheenjohtajan tervehdys. Petsamolaista, 3.

Mosorin, Y. (1984). Puheenjohtajan tervehdys. Petsamolaista, 18.

Neuvostoliiton ja Suomen matkailuyhteistyö (1976). Matkailusilmä, 2/1976, 2-3. 
Niemi, E. (1995). The Finns in Northern Scandinavia and minority policy. In S. Tägil (Ed.), Ethnicity and nation building in the Nordic World (pp. 145-178). London: Hurst \& Co.

Nora, P. (1989). Between memory and history: Les Lieux de Mémoire. Representations, 26, 7-24. https://doi.org/10.2307/2928520

Nora, P. (1996). General introduction: Between memory and history. In P. Nora \& L. Kritzman (Eds.), Realms of memory: The construction of the French past. Volume 1 (pp. 1-20). New York: Columbia University Press.

Ooms, J. (2017). Magick: Advanced graphics and image-processing in R. R package, version 1.6. Retrieved from https://CRAN.R-project.org/package=magick

Orlov, I. (2014). The Soviet Union outgoing tourism in 1955-1985. (Working papers. Higher School of Economics.) Moscow: National Research University.

Pennanen, J. (2000). Jos ei ole poropaimenia, kansa häviää: Kuolan poronhoitajien sosiokulttuurinen adaptaatio 20. vuosisadalla. Helsinki: Suomalaisen Kirjallisuuden Seura.

Petsamon itsenäisyyspatsas (1939). Lapin Kansa, 14/12/1939.

Petsamon laulu (1978). Petsamolaista, 23.

Petsamon siirtoväki ry. (1978). Petsamolaista, 5.

Phillips, K. R., \& Reyes, G. M. (2011). Global memoryscapes: Contesting remembrance in a transnational age. Tuscaloosa: University of Alabama Press.

Raninen-Siiskonen, T. (2013). Karjalaisen siirtoväen sopeutuminen tutkimusten kohteena. In P. Suutari (Ed.), Karjala-kuvaa rakentamassa (pp. 122-155). Helsinki: Suomalaisen Kirjallisuuden Seura.

Rantala, L. (2008). Kuolaan: Venäjän vallan aikana Kuolan niemimaalla käyneet suomalaiset tiedemiehet ja heidän kirjoituksensa. Rovaniemi: Lapin yliopisto.

Rantala, L. (2013). Retki Vaarlamansaarelle 2012 ja sen uutisointia. Petsamolaista, 26-28.

Rantala, L. (2014). Sotavankeus, mutta toisinpäin. Petsamolaista, 86-89.

Rautio, V. (2003). The potential for community restructuring: Mining towns in Pechenga. Helsinki: University of Helsinki.

R Core Team (2017). R: A language and environment for statistical computing. R Foundation for Statistical Computing, Vienna, Austria. Retrieved from https://www.R-project.org/

Rosenwein, B. H. (2010). Problems and methods in the history of emotions. Passions in Context, I(1/2010), 1-32. Retrieved from http://www.passionsincontext.de/uploads/media/o1_Rosenwein.pdf

Savolainen, U. (2015). Muistettu ja kirjoitettu evakkomatka. Joensuu: Suomen Kansantietouden Tutkijain Seura.

Savukoski, J. (1993). Hyvät Petsamo-Seuran jäsenet, hyvät ystävät! Petsamolaista, 3. 
Sergejeff, K. (1990). Matkalta synnyinseudulle. Petsamolaista, 41-52.

Shephard, B. (2011). The long road home: The aftermath of the Second World War. London: Vintage Books.

Smith, L. (2005). Uses of heritage. London: Routledge.

Soini, T. (1980). Matka menneeseen maisemaan. Petsamolaista, 13.

Soini, T. (1983). Muistot - elämänvoima. Petsamolaista, 5.

Suomen ja Neuvostoliiton yhteistyöohjelma (1980). Matkailusilmä, 3/1980, 18-19.

Sverloff, M. (2003). Suenjelin saamelainen perintö. Helsinki: Maa- ja metsätalousministeriö.

Tanner, V. (1929). Antropogeografiska studier inom Petsamo-området, 1: Skoltlapparna. (Fennia, 49.) Helsingfors: Societas geographica Fenniae.

Tazim, J., \& Robinson, M. (Eds.) (2009). The Sage handbook of tourist studies. London: SAGE.

Tolia-Kelly, D. (2004). Locating processes of identification: Studying the precipices of re-memory through artefacts in the British Asian homes. Transactions of the Institute of British Geographers, 29, 314-329. https://doi.org/10.1111/j.0020-2754.2004.00303.x

Tolkki, M.-L. (1992). Petsamolaista. Petsamolaista, 5.

Tuunainen, P. (2017). The Finns - experts in winter warfare. In M. Lähteenmäki, Footprints in the snow: The long history of Arctic Finland (pp. 97-104). (Prime Minister's Office Publications, 12/2017). Helsinki. Retrieved from https:/julkaisut.valtioneuvosto.fi/bitstream/handle/10024/80043/VNK_J1217_Footprints\%20in\%20the\%20snow_net.pdf?sequence=1

UNWTO. (2010). Annual report: Statistics guidelines. Retrieved from http://cf.cdn.unwto.org/sites/ all/files/pdf/final_annual_report_pdf_3.pdf

Uola, M. (2012). Petsamo 1939-1944. Helsinki: Minerva.

Vahtola, J., \& Onnela, S. (Eds.) (1999). Turjanmeren maa: Petsamon historia 1920-1944. Rovaniemi: Petsamo-seura.

Vuorisjärvi, E. (1990). Petsamon nikkeli kansainvälisessä politiikassa 1939-1944: Suomalainen todellisuus vastaan ulkomaiset myytit. University of Helsinki.

Young, J. E. (2018). Remembering the Holocaust: Holocaust history, memory and art. In My Jewish Learning homepage. Retrieved from https:/www.myjewishlearning.com/article/ remembering-the-holocaust/

Äärelä, U. (1982). Tämän päivän Petsamo. Petsamolaista, 20-23. 


\section{Source material}

FINNA database 1945-2015. National Library of Finland. Retrieved 15 December 2018 from https://www.finna.fi/

Helsingin Sanomat 1990-2015.

Matkailusilmä 1976-2015.

Petsamolaista 1970-2015.

Movies:

Nikkeli-Petsamo in 1999. Petsamo Society.

On the road in Liinahamari 6/7/2013. Petsamo Society.

On the road in Petsamo 1-5/7/1999. Petsamo Society.

On the road in Petsamo 12-15/6/2002. Petsamo Society.

Our memories: Petsamo 4-7/9/1997. Petsamo Society.

Petsamo 1999. Petsamo Society. Petsamo Society.

Petsamo-Murmansk 16-19/6/2005. Petsamo Society.

Radio program. Petsamon siirtoväkeä. Journalist Niilo Ihamäki. YLE Finland 14/8/1956. 